\title{
Reproductive Biology of Bryconamericus stramineus Eigenmann, 1908 (Ostariophysi: Characidae) from the Rio Ibicuí, RS, Brazil
}

\author{
Vinicius Renner Lampert*, Marco Aurélio Azevedo and Clarice Bernhardt Fialho \\ Departamento de Zoologia; Laboratório de Ictiologia; Universidade Federal do Rio Grande do Sul; Av. Bento \\ Gonçalves, 9500; 90540-000; vlampert@ufrgs.br; Porto Alegre - RS - Brasil
}

\begin{abstract}
Reproduction of Bryconamericus stramineus was described based on the analysis of 208 females and 166 males collected monthly in the Rio Ibicuí, from April 2001 through March 2002. Reproduction occurred between September and December, with a lower peak in February. The mean absolute fecundity was $371.3( \pm 244.6)$ oocytes and the mean relative fecundity was $0.35( \pm 0.08)$ oocytes/mg of total weight and the fish was a multiple spawner. A weak correlation between GSI of males and day length was observed. Other parameters (stomach repletion and hepatosomatic index, rainfall and temperature) did not show any correlation with GSI. However, some of these factors might act as "starters" of gonadal maturation. The presence and frequency of fin ray hooks on the males was compared with the gonadal maturation stages, months and standard length classes. Well-developed hooks were found mainly in the mature males during the reproductive period and in the largest individuals.
\end{abstract}

Key words: Reproductive period, fecundity, spawning type, Bryconamericus, fin-ray hooks

\section{INTRODUCTION}

The family Characidae has 1352 species: 952 are valid species and 400 are not yet described. Bryconamericus Eigenmann et al. (1907) is one of the 88 genera of the family listed as incertae sedis, with 51 described species (Reis et al., 2003). According to Britski et al. (1988), the fishes of this genus usually do not exceed $10 \mathrm{~cm}$ of length, live in diversified environments, and are mostly omnivorous and active species, that also serve as food for other fishes. Species of Bryconamericus occur in a wide range of freshwater ecosystems in the Central and South America, from Costa Rica to the Western Argentina, on both sides of the Andes cordillera (Vari and Siebert, 1990). According to
Silva (1998), there are 15 species of Bryconamericus in South and Southeast Brazil. The species B. stramineus Eigenmann, 1908 occur in the Prata and São Francisco river basins, in Argentina, Brazil, Paraguay and Uruguay.

Reproduction is the process that ensures the preservation and abundance of a species and reproductive success depends on where and when the species reproduces and on the resources allocated for their reproduction (Wootton, 1990). This is determined by the capacity of their members to reproduce in the variable environments, maintaining viable populations (Vazzoler, 1996). According to Menezes and Vazzoler (1992), more scientific work must be done in order to get a better comprehension about

Author to for correspondence 
the main reproductive patterns in Characiformes. This information is very important to establish the measures of conservation and natural resource management.

Despite being common and abundant in these environments, few studies have been conducted regarding the reproduction of Bryconamericus species. Some examples can be found in Godoy (1975), Kramer (1978), Winemiller (1989), Nakatani et al. (2001) and Lampert et al. (2004). However, only Lampert et al. (2004) provided information concerning the development of secondary sexual characters. The aim of this work was to describe the reproductive period, fecundity and spawning of $B$. stramineus in the Rio Ibicuí, Rio Grande do Sul State, and to verify possible relationships between the reproduction and biotic/abiotic factors. Furthermore, this work aimed also to describe the occurrence of secondary sexual characters (hooks on pelvic and anal fins of males) and the possible relationships of these with the reproductive period, with gonadal maturation and individual body length.

\section{MATERIALS AND METHODS}

Monthly samples in the Rio Ibicuí (29 50'14"'S and $54^{\circ} 47^{\prime} 53^{\prime \prime} \mathrm{W}$ ) near Rosário do Sul were made between April 2001 through March 2002 using a seine $(5 \mathrm{~mm}$ mesh size). Water temperature was measured in the field $(20-50 \mathrm{~cm}$ deep), the day length was obtained with a GPS (monthly mean values of sunlight - intervals between sunrise and sunset) and the 8th District of Meteorology of Porto Alegre provided rainfall data. The specimens were fixed in $10 \%$ formalin and the measurements of standard length $(L S-\mathrm{mm})$ and total body weight $(\mathrm{Wt}-\mathrm{g})$ were taken in the laboratory. Voucher specimens were catalogued in the fish collection of Universidade Federal do Rio Grande do Sul (UFRGS 6693). The specimens were dissected, and the gonads, stomach and liver weighed and preserved in Ethanol 70\%. A macroscopic characterization of the gonadal maturation stages was made for the males and females, according to the following description:

Immature (IMT) - small, filamentous, translucent and undeveloped testis; small ovaries, generally transparent, with undeveloped oocytes; Maturing (MTG) - solid and compact testis with milky coloration having $1 / 3$ to $2 / 3$ of the size of mature gonads; ovaries with oocytes of different sizes with yellowish coloration; Mature (MAT) - large testis with white coloration, sometimes yellowish, occupying about $1 / 4$ of the visceral cavity; ovaries with well developed oocytes with yellow or orange coloration; Spawning (SPW) - not identified in males; ovaries slightly flaccid and presence of reserve and yolky oocytes; Spent (SPT) - reduced and flaccid testis; ovaries with a disarranged aspect containing small oocytes and absence of yolky oocytes. With the data obtained, the Gonadosomatic Index - GSI (Vazzoler, 1996), Stomach Repletion Index - SRI and Hepatosomatic Index - HSI (Santos, 1978) were calculated. These indexes represent the percentage of the organ weight in relation to total fish weight. The monthly variation of the mean values of GSI plus the relative frequencies of the gonadal maturation stages indicates the reproductive period of the species along the study period. The nonparametric Spearman test was applied to the mean values of GSI and the monthly averages of SRI, HSI, rainfall, day length and temperature to verify possible relationships between reproduction and biotic/abiotic factors.

The absolute fecundity of the species was estimated by counting all the yolky oocytes present in 26 mature ovaries of females ranging from 25.84 to $52.88 \mathrm{~mm} \mathrm{LS}$. These ovaries were immersed in Gilson's solution, according to Vazzoler (1996) to release the oocytes from the ovarian tissue and the oocytes were counted under a stereomicroscope. Relative fecundity, as suggested by Adebisi (1987), was calculated as the number of oocytes per milligram of female weight. The values of total fecundity were tested through regression analysis with standard length, total weight and gonad weight to verify how they were related. The spawning type was established through the analysis of 31 ovaries representing the different gonadal maturation stages. In each ovary, 150 oocytes were sub-sampled and their largest diameters was measured (Vazzoler, 1996). Measurements were taken using an ocular micrometer in the stereomicroscope and the oocyte diameters were grouped into size classes of $0.05 \mathrm{~mm}$ intervals. The variations of frequencies of each oocyte diameter interval class were analyzed according to gonadal maturation stage (Vazzoler, 1996). The presence of hooks on the anal and pelvic fins of males was observed under a stereomicroscope and classified according to four degrees of development: (i) absent: without hooks on both fins; (ii) less developed: small hooks, in 
small number, visible mainly on the pelvic fins; (iii) developed: larger hooks, in large numbers, observed on anal and pelvic fins; (iv) well developed: large, numerous and slightly curved hooks, easily identified on anal and pelvic fins. The presence, frequency and development of hooks were analyzed on the pelvic and anal fins. The data on hook frequency was compared with the gonadal maturation stages, months and standard length classes. Seven standard length classes were established, at $4 \mathrm{~mm}$ intervals each: Class $1-17.09$ a 21.09mm; Class $2-21.09$ a 25.09mm; Class 3 - 25.09 a $29.09 \mathrm{~mm}$; Class $4-$ 29.09 a $33.09 \mathrm{~mm}$; Class $5-33.09$ a $37.09 \mathrm{~mm}$; Class $6-37.09$ a $41.09 \mathrm{~mm}$; Class $7-41.09$ a $45.09 \mathrm{~mm}$.

\section{RESULTS}

We analyzed 208 females (ranging from 16.96 to $66.3 \mathrm{~mm}$ of $L S$ ) and 166 males (ranging from 17.09 to $44.58 \mathrm{~mm}$ of $L S$ ) of $B$. stramineus. The values of GSI in both sexes began to increase slightly in September, reaching highest values in October and November, and decreasing after this. Another small increase can be observed in February, also in both sexes (Fig. 1a-b).

The relative frequencies of gonadal maturation stages (Fig. 2a-b) showed that mature females occurred with higher frequencies in October and November and spawning and spent females occurred mainly in February and March. Mature males were found from August to March, with highest frequencies in October, November and February, indicating the reproductive period of the species. Maturing males occurred in all the months except November, where all the individuals were considered as mature.
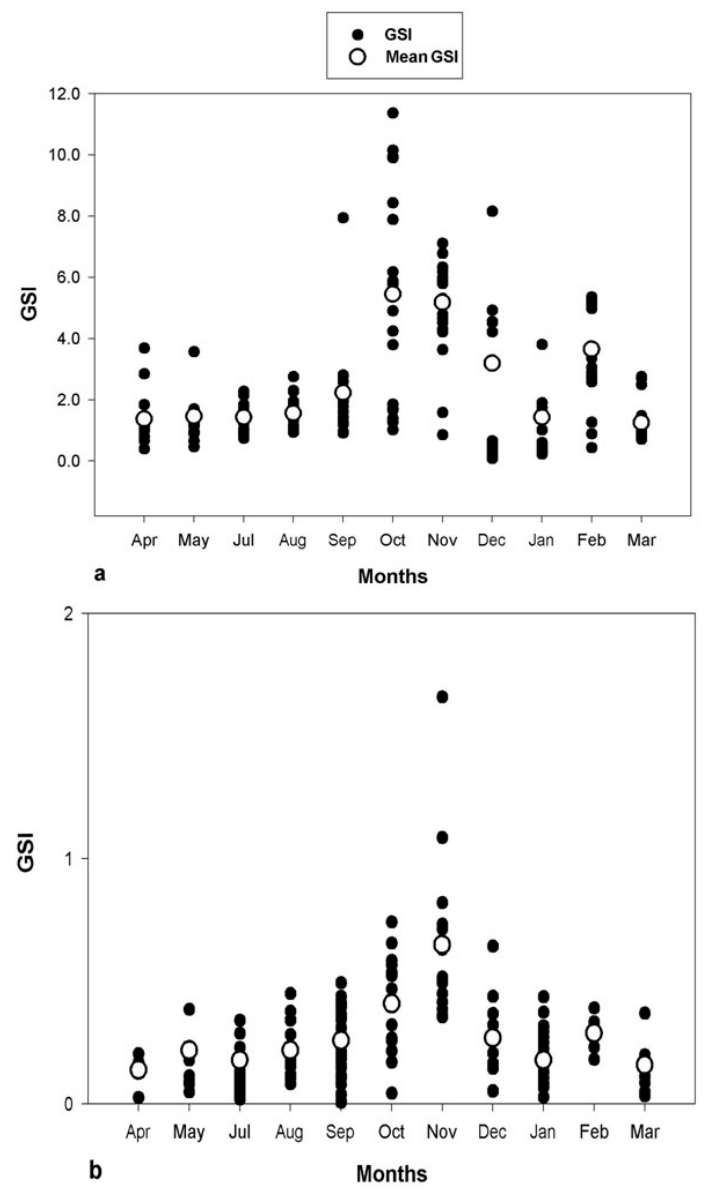

Figure 1 - Monthly values of the gonadosomatic index - GSI - (black circles) and the mean values (white circles) in female (a) and male (b) Bryconamericus stramineus 


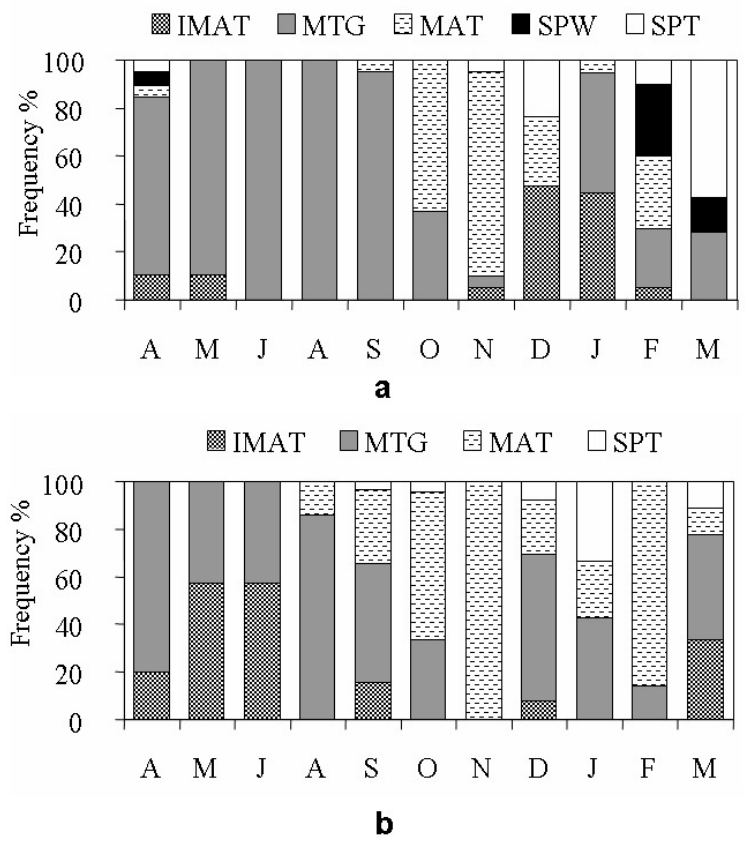

Figue 2 - Frequency of occurrence of the gonadal maturation stages in females (a) and males (b) of Bryconamericus stramineus. $\mathrm{IMT}=$ immature; $\mathrm{MTG}=$ maturing; $\mathrm{MAT}=$ mature; $\mathrm{SPW}$ = spawning; $\mathrm{SPT}=$ spent

Neither male or female GSI showed a significant correlation with any of the factors measured (Table 1). The monthly averages of SRI in females and males showed high values in September, November and March, before and after the peaks of GSI. The monthly averages of HSI showed stable values throughout the year but a fall in October, together with the peak of GSI. Rainfall averages varied along the year, exhibiting a peak in September, before the peak of GSI to both sexes, which occured in October and November.
The day length increases in October and November, with a peak in December, coincided with the period in which GSI of females and males was higher. The temperature increased in October and November coinciding with the increase of GSI of females and males in that period (Table 2).

The absolute fecundity of $B$. stramineus varied from 98 to 1100 oocytes. Mean absolute fecundity of this species was $371.3( \pm 244.6)$ oocytes and the mean relative fecundity was 0.35 ( \pm 0.08$)$ oocytes/mg of total weight.

Table 1 - Spearman correlation test between mean values of GSI and rainfall, day length, temperature, SRI and HSI to females and males of Bryconamericus stramineus. GSI = gonadosomatic index; SRI = stomach repletion index; HSI $=$ hepatosomatic index.

\begin{tabular}{lccc}
\hline & Sex & $\mathbf{r}$ & $\mathbf{p}$ \\
\hline GSI x rainfall & Females & -0.3280 & 0.3247 \\
& Males & -0.1640 & 0.6299 \\
GSI x day length & Females & 0.4829 & 0.1324 \\
& Males & 0.5695 & 0.0674 \\
GSI x temperature & Females & 0.0913 & 0.7894 \\
& Males & 0.3508 & 0.2187 \\
GSI x SRI & Females & -0.1822 & 0.5950 \\
& Males & -0.0547 & 0.8812 \\
GSI x HSI & Females & 0.4315 & 0.1826 \\
\hline
\end{tabular}


Table 2 - Monthly variation of the mean values of GSI, SRI and HSI ( \pm SD), number of females and males $(N)$ of Bryconamericus stramineus and rainfall, day length and temperature data. GSI = gonadosomatic index; SRI = stomach repletion index; HSI = hepatosomatic index.

\begin{tabular}{|c|c|c|c|c|c|c|c|c|c|c|}
\hline Months & $\begin{array}{c}\text { GSI } \\
q\end{array}$ & $\begin{array}{c}\text { SRI } \\
+\end{array}$ & $\begin{array}{c}\text { HSI } \\
q\end{array}$ & $\begin{array}{l}\mathbf{N} \\
\text { q }\end{array}$ & $\underset{0}{\mathbf{G S I}}$ & $\underset{\hat{\sigma}}{\mathbf{S R I}}$ & $\begin{array}{l}\mathbf{N} \\
0\end{array}$ & $\begin{array}{c}\text { Rainfall } \\
(\mathbf{m m})\end{array}$ & $\begin{array}{c}\text { Day } \\
\text { length } \\
\text { (min.) }\end{array}$ & $\begin{array}{c}\text { Temperature } \\
\left({ }^{\circ} \mathbf{C}\right)\end{array}$ \\
\hline APR & $\begin{array}{c}1.39 \\
\pm 0.77\end{array}$ & $\begin{array}{c}3.48 \\
\pm 1.35\end{array}$ & $\begin{array}{c}1.02 \\
\pm 0.47\end{array}$ & 19 & $\begin{array}{c}0.14 \\
\pm 0.08\end{array}$ & $\begin{array}{c}3.19 \\
\pm 0.74\end{array}$ & 5 & 388.5 & 696 & 24.1 \\
\hline MAY & $\begin{array}{c}1.47 \\
\pm 0.58\end{array}$ & $\begin{array}{c}2.57 \\
\pm 0.63\end{array}$ & $\begin{array}{c}2.08 \\
\pm 0.88\end{array}$ & 19 & $\begin{array}{c}0.22 \\
\pm 0.14\end{array}$ & $\begin{array}{c}2.75 \\
\pm 0.93\end{array}$ & 7 & 196.8 & 641 & 17 \\
\hline JUN & & & & & & & & 319.2 & 614 & \\
\hline JUL & $\begin{array}{c}1.44 \\
\pm 0.43\end{array}$ & $\begin{array}{c}2.20 \\
\pm 0.68\end{array}$ & $\begin{array}{c}1.05 \\
\pm 0.46\end{array}$ & 19 & $\begin{array}{c}0.18 \\
\pm 0.09\end{array}$ & $\begin{array}{c}2.57 \\
\pm 0.73\end{array}$ & 21 & 162.8 & 617 & 17.7 \\
\hline AUG & $\begin{array}{c}1.57 \\
\pm 0.53\end{array}$ & $\begin{array}{c}2.85 \\
\pm 1.53\end{array}$ & $\begin{array}{c}1.34 \\
\pm 0.50\end{array}$ & 17 & $\begin{array}{c}0.22 \\
\pm 0.10\end{array}$ & $\begin{array}{c}2.77 \\
\pm 0.64\end{array}$ & 21 & 116.9 & 648 & 20.1 \\
\hline SEP & $\begin{array}{c}2.24 \\
\pm 1.49\end{array}$ & $\begin{array}{c}4.20 \\
\pm 1.30\end{array}$ & $\begin{array}{c}1.64 \\
\pm 0.70\end{array}$ & 19 & $\begin{array}{c}0.26 \\
\pm 0.12\end{array}$ & $\begin{array}{c}4.49 \\
\pm 1.42\end{array}$ & 26 & 430.4 & 722 & 17.8 \\
\hline OCT & $\begin{array}{c}5.46 \\
\pm 3.44\end{array}$ & $\begin{array}{c}1.48 \\
\pm 0.40\end{array}$ & $\begin{array}{c}1.35 \\
\pm 0.50\end{array}$ & 19 & $\begin{array}{c}0.41 \\
\pm 0.20\end{array}$ & $\begin{array}{c}1.50 \\
\pm 0.47\end{array}$ & 21 & 181.6 & 778 & 22.5 \\
\hline NOV & $\begin{array}{c}5.19 \\
\pm 1.39\end{array}$ & $\begin{array}{c}3.77 \\
\pm 1.77\end{array}$ & $\begin{array}{c}1.26 \\
\pm 0.36\end{array}$ & 20 & $\begin{array}{c}0.65 \\
\pm 0.34\end{array}$ & $\begin{array}{c}4.11 \\
\pm 1.85\end{array}$ & 15 & 174.5 & 836 & 22.9 \\
\hline DEC & $\begin{array}{c}3.20 \\
\pm 2.72\end{array}$ & $\begin{array}{c}2.56 \\
\pm 0.85\end{array}$ & $\begin{array}{c}1.23 \\
\pm 0.35\end{array}$ & 17 & $\begin{array}{c}0.27 \\
\pm 0.16\end{array}$ & $\begin{array}{c}2.70 \\
\pm 0.81\end{array}$ & 13 & 63.6 & 846 & 27 \\
\hline JAN & $\begin{array}{c}1.44 \\
\pm 0.97\end{array}$ & $\begin{array}{c}1.51 \\
\pm 0.45\end{array}$ & $\begin{array}{c}1.28 \\
\pm 0.22\end{array}$ & 18 & $\begin{array}{c}0.18 \\
\pm 0.12\end{array}$ & $\begin{array}{c}1.63 \\
\pm 0.69\end{array}$ & 21 & 84.8 & 817 & 26 \\
\hline FEB & $\begin{array}{c}3.66 \\
\pm 1.39\end{array}$ & $\begin{array}{c}2.22 \\
\pm 0.72\end{array}$ & $\begin{array}{c}1.03 \\
\pm 0.22\end{array}$ & 20 & $\begin{array}{c}0.29 \\
\pm 0.07\end{array}$ & $\begin{array}{c}2.11 \\
\pm 0.50\end{array}$ & 7 & 23.4 & 808 & 24 \\
\hline MAR & $\begin{array}{c}1.24 \\
\pm 0.63\end{array}$ & $\begin{array}{c}3.07 \\
\pm 1.36\end{array}$ & $\begin{array}{c}0.80 \\
\pm 0.17\end{array}$ & 21 & $\begin{array}{c}0.16 \\
\pm 0.12\end{array}$ & $\begin{array}{c}2.60 \\
\pm 0.81\end{array}$ & 9 & 342.6 & 753 & 22.5 \\
\hline
\end{tabular}

The relationships of absolute fecundity with standard length and with total weight were adjusted to a potential equation $\left(\mathrm{y}=0.0055 \mathrm{x}^{3.0183}\right.$; $\mathrm{r}=0.93$ and $\mathrm{y}=342.53 \mathrm{x}^{0.9471} ; \mathrm{r}=0.93$; respectively), while the relationship of absolute fecundity with gonads weight was adjusted to a linear equation $(y=3312 x+120.49 ; r=0.92)$.All gonadal maturation stages showed a high frequency of small diameter oocytes (Fig. 3), while in the mature stage, it was possible to observe several modes of larger diameter oocytes. They represented, respectively, reserve oocytes and oocytes to be released during the reproductive period, which characterized the species as a multiple spawner. The absence of large diameter oocytes in the spent stage suggested the end of the spawning period.

The development of hooks was similar on the pelvic and anal fins, and therefore the results were analyzed together. The analysis of frequency of occurrence of hooks on the fins related to the gonadal maturation stages in males of $B$. stramineus (Fig. $4 a$ ) showed that about $72 \%$ of the mature males had well developed hooks; developed hooks were present mainly in the maturing males, but they also appeared in the mature and spent males. Hooks were absent in immature and maturing individuals; some immature males had less developed hooks. The monthly frequency (Fig. 4b) showed that from September to November there was a greater number of individuals with well developed hooks, coinciding with months which showed the highest mean values of GSI. Individuals with developed hooks did not appear in May/2001 and March/2002. Males without hooks (absent category) occurred mainly in May (about $86 \%$ ).

The frequency of hooks by standard length class (Fig. 4c) showed that individuals belonging to the larger classes (4 to 7) had well developed hooks, while individuals of the classes 1 and 2, mainly, but also of the classes 3 to 5, lacked hooks. Individuals with less developed hooks occurred in all the standard length classes, as well as those with developed hooks, except for the class 1 . 

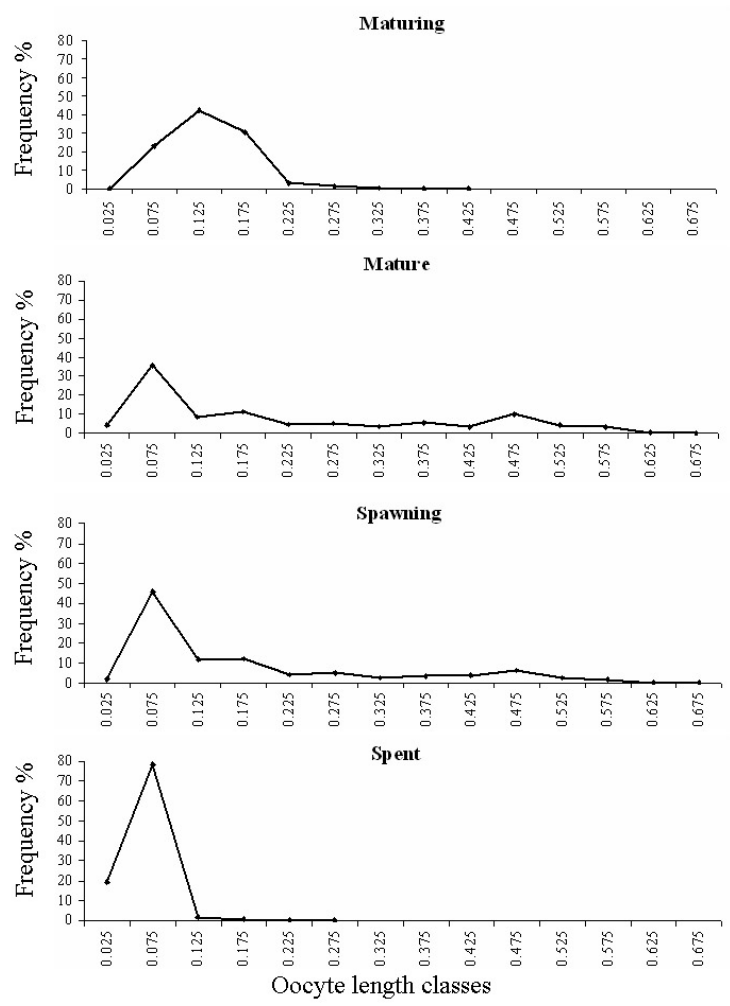

Figure 3 - Relative frequency distribution of oocytes diameters in the different gonadal maturation stages in Bryconamericus stramineus. Number of analyzed gonads in each stage: maturing (9), mature (6), spawning (8) and spent (8)
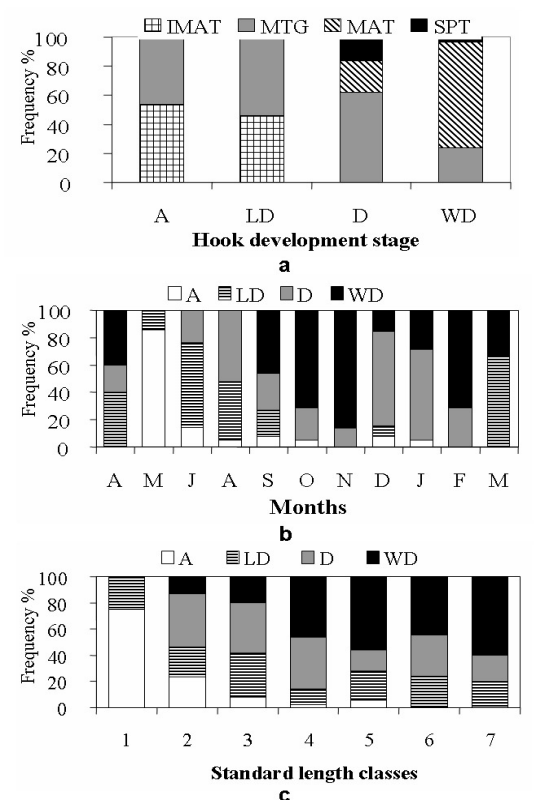

Figure 4 - Frequency of occurrence of hooks (a) by gonadal maturation stages; (b) by month and (c) by standard length classes in males of Bryconamericus stramineus. IMT = immature; $\mathrm{MTG}=$ maturing; MAT = mature; $\mathrm{SPT}=$ spent; $\mathrm{A}=$ absent; $\mathrm{LD}=$ less developed; $\mathrm{D}$ = developed; $\mathrm{WD}=$ well developed 


\section{DISCUSSION}

There is little information concerning the reproduction of Bryconamericus species. Kramer (1978), studying a population of B. emperador Eigenmann and Ogle, 1907 in Panama, characterized the reproductive period of that species as extremely short, in which most of the population spawned on only one or two days per year, during the flood period in June. Winemiller (1989) observed that a population of B. beta Eigenmann, 1914 from the Venezuelan Llanos reproduced throughout the year, showing multiple spawning, in a strategy characterized as "opportunistic". According to Godoy (1975), the reproductive period of B. stramineus from the Rio Mogi Guaçu, Paraná, extended from September to January. Lampert et al. (2004), studying $B$. iheringii Boulenger, 1887 from the Rio Vacacaí in the state of Rio Grande do Sul, reported that the species reproduced between September and January.

Vazzoler and Menezes (1992) found that several characid species had their reproductive period during spring and summer, being controlled by one or more biotic and/or abiotic factors. Many works with characids from Rio Grande do Sul showed similar reproductive seasonality, such as Serrapinnus calliurus Boulenger, 1900 (Gelain et al., 1999), Diapoma speculiferum Cope, 1894 (Azevedo et al., 2000), Cheirodon ibicuhiensis Eigenmann, 1915 (Oliveira et al., 2002), Odontostilbe pequira Steindachner, 1882 (Oliveira, 2003), Diapoma terofali Géry, 1964 (Azevedo, pers. commun.) and Aphyocharax anisitsi Eigenmann and Kennedy, 1903 (Gonçalves, pers. commun.) and also, B. iheringii (Lampert et al., 2004). The mean values of GSI to most of these species showed a strong correlation with the increase in day length and temperature. The reproductive seasonality observed in $B$. stramineus agreed with the general pattern described in other characids of the subtropical region. Despite the lack of correlation observed, it is supposed that day length and temperature could have an important role in the reproductive cycle of the species, acting as "starters" of gonadal maturation. Also, perhaps a larger sample size in the present study would have resulted in significant correlations of GSI with day length and/or temperature.
Some biotic factors can also be related with the reproduction. The values of SRI and HSI suggested that during the reproductive period, this species tended to feed less than in other months. More intense feeding, during non-reproductive months, could represent a strategy for the energy storage to be used for the vitellogenesis during the reproductive season (Barbieri et al., 1996).

Spawning type and fecundity, especially relative fecundity, are not well discussed in fish reproduction studies. Usually, the data concerning fecundity do not take into account the individual's size or weight, or even if the fecundity value refers to an oocyte batch or to the whole reproductive period. This makes comparisons among species all the more difficult. Fecundity can be a variable characteristic. It can change among species and within individuals of the same species. Also, can change among individuals of the same size within a reproductive period, between successive reproductive periods as well as with latitude (Vazzoler, 1996). Thus, generalizations on fecundity should be made carefully (Vazzoler and Menezes, 1992).

Small sized characids (less than $10 \mathrm{~cm}$ ), which are externally fertilized, such as Serrapinnus calliurus (Gelain et al., 1999), Cheirodon ibicuhiensis (Oliveira et al., 2002), Odontostilbe pequira (Oliveira, 2003) and Aphyocharax anisitsi (Gonçalves, 2005), show higher values of relative fecundity than inseminating species such as Diapoma speculiferum (Azevedo et al., 2000) Mimagoniates rheocharis Menezes and Weitzman, 1990 and $M$. microlepis Steindachner, 1876 (Azevedo, 2000) and Pseudocorynopoma doriae Perugia, 1891 (Melo, pers. commun.). The absolute and relative fecundities in $B$. stramineus are lower than in other members of the family that engage in external fertilization. Moreover, the values of relative fecundity were similar to those observed in inseminating species. Species that have low fecundity usually show other traits such as parental care, insemination, internal fertilization or multiple spawning, because these strategies may offer to eggs and larvae, higher chances of fertilization and/or survival. (Vazzoler and Menezes, 1992; Azevedo, 2000; Azevedo et al., 2000).

The four inseminating species mentioned above along with several other genera (including Bryconamericus) form a natural clade within 
Characidae, sharing synapomorfies related to dorsal fin rays and teeth (Malabarba and Weitzman, 2003). The low fecundity found in $B$. stramineus and glandulocaudine species (Azevedo, 2000; Azevedo et al., 2000) could be a result of common ancestry, independent of insemination or any other characteristic related to parental care.

Regression analysis between the absolute fecundity and standard length, and absolute fecundity and total weight, showed that the weight and length were good indicators of oocyte production capacity. However, length could be a better indicator of oocyte production capacity than weight, because length did not decrease while weight could vary throughout the year (Bagenal, 1967). However, gonads weight was a more reliable indicator of oocyte production capacity, because it showed a linear relation with fecundity, indicating that the two variables increased proportionally.

According to Vazzoler (1996), the spawning type is the way in which females release their mature oocytes within a reproductive period. Vazzoler (1996) reported that the multiple spawning strategy was related to oocyte development "synchronic in more than two groups" in which oocytes of each batch developed in synchrony, being released when they reached total maturation, occurring through successive elimination of mature oocyte batches. However, a higher annual reproductive effort than reached with a single spawning would be necessary to support the multiple spawning (Burt et al., 1988). Multiple spawning represents a strategy through which certain species increase the number of oocytes produced in a reproductive period to higher levels than would be predictable, considering their length. B. stramineus as a multiple spawner can produce more than one oocyte batch, increasing the number of oocytes produced throughout the spawning season. Thus, multiple spawning may represent an advantage that may increase reproductive success, specially for small species unable to store a large amount of oocytes. Therefore, the low fecundity values obtained for $B$. stramineus in this study should be understood as the fecundity in each oocytes batch and not as the fecundity to the whole reproductive period.

According to Malabarba and Weitzman (2003), the presence of hooks on the anal - and pelvic - fin rays of males, often on the caudal fin and rarely on the dorsal and/or pectoral fins, has been described in Gasteropelecidae, Serrasalminae and in several
Characidae species. The hooks might differ greatly in shape, position and possibly function among species of these groups, but they were always observed as bony-spiny processes developed on the surface of individual segments of lepidotrichia (Malabarba and Weitzman, 2003). These hooks may represent an expression of a gene or genes absent in other American or African Characiformes, as well as absent in Siluriformes and Cypriniformes (Malabarba and Weitzman, 2003). It suggests that fin ray hooks are a derived character and a synapomorphy for some subgroups of Characiformes. According to Wiley and Collette (1970), the true function of the fin ray hooks is not well understood and they suggest that these structures may work as contact organs to keep males and females closer to each other during the movements of the spawning act. Garutti (1990) and von Ihering and Azevedo (1936) reported that the occurrence of hooks in Astyanax bimaculatus Linnaeus, 1758 was seasonal, coinciding with the reproductive period, being lost when it was over. On the other hand, Andrade et al. (1984) studied the same species and concluded that the hooks were a permanent characteristic in adult males. Studying two glandulocaudine species, Mimagoniates microlepis and M. rheocharis, Azevedo (2000) suggested that the hooks could be associated with their peculiar courtship behaviour and that were not lost after the reproduction, once they could be found in males with spent gonads, at the end of the reproductive period. In $B$. stramineus, well developed hooks were frequent during the reproductive period, decreasing in the following months. This could be attributed to the recruitment of young individuals in the population, not necessarily to the loss of hooks. Hooks were present even in the spent males, which suggested that they were not lost after the reproduction. In larger individuals, well developed hooks were always present, even after the reproductive period. However, in intermediary length classes, there were males without hooks and males with developed hooks. Thus, the development of fin ray hooks seemed to be related more to the development and maturation of the gonads than to the increase in the individual's body size.

\section{ACKNOWLEDGEMENTS}

We thank to the colleagues of the Laboratório de Ictiologia da UFRGS for their help in field and 
laboratory work and to $\mathrm{CNPq}$ (proc.464545/00-5 and 476821/2003-7) and CAPES for financial support.

\section{RESUMO}

A reprodução de Bryconamericus stramineus é descrita baseada na análise de 208 fêmeas e 166 machos coletados mensalmente no rio Ibicuí, RS, de abril/2001 a março/2002. A reprodução ocorreu entre setembro e dezembro, com um pico menor em fevereiro. A fecundidade absoluta média é de 371.3 ( \pm 244.6$)$ ovócitos e a fecundidade relativa média é de 0.35 ( \pm 0.08$)$ ovócitos/mg de peso total e a espécie tem desova parcelada. Foi observada uma fraca correlação entre IGS de machos e fotoperíodo; os índices de repleção estomacal e hepatossomático, a pluviosidade e temperatura não mostraram nenhuma correlação. Porém, sugerimos que alguns destes fatores possam agir como "desencadeadores" da maturação gonadal. A presença e freqüência de ganchos nas nadadeiras de machos foi comparada com as fases de maturação gonadal, meses e classes de comprimento padrão. Ganchos bem-desenvolvidos foram encontrados principalmente em machos maduros, durante o período reprodutivo e nos indivíduos maiores.

\section{REFERENCES}

Adebisi, A. A. (1987), The relationships between fecundities, gonadosomatics indices and egg sizes of some fishes of Ogun River, Nigéria. Archiv für Hydrobiologie, 111:151-156.

Andrade, D. R., E. Menin and S. P. Ribeiro. (1984), Periodicidade da característica sexual secundária em Astyanax bimaculatus (Linnaeus, 1758) Pisces, Characidae. Revista Seiva, 44(93): 9-12.

Azevedo, M. A. (2000), Biologia reprodutiva de dois glandulocaudíneos com inseminação, Mimagoniates microlepis e Mimagoniates rheocharis (Teleostei: Characidae), e características de seus ambientes. M. Sc. Dissertation. Programa de Pós-Graduação em Biologia Animal, Universidade Federal do Rio Grande do Sul, Porto Alegre, Brasil. 84p.

Azevedo, M. A., L. R. Malabarba and C. B. Fialho. (2000), Reproductive biology of the inseminated Glandulocaudine Diapoma speculiferum Cope 1894 (Actinopterygii: Characidae). Copeia, 2000 (4): 983989.
Bagenal, T. B. (1967), A short review of fish fecundity. P 89-111, In: Shelby, D. Gergink (ed.). The biological basis of freshwater fish production. Blackwell, Oxford.

Barbieri, G., S. M. Hartz and J. R. Verani. (1996), O fator de condição e índice hepatossomático como indicadores do período de desova de Astyanax fasciatus da represa do Lobo, São Paulo (Osteichthyes, Characidae). Iheringia, Sér. Zool. (81): 97-100.

Britski, H. A, Y. Sato and A. B. S. Rosa. (1988), Manual de Identificação de Peixes da Região de Três Marias - com chave e identificação para os peixes da bacia do rio São Francisco. Brasília, Ed. Ministério da Irrigação - CODEVASF, 3 ed., 115p.

Burt, A. D. L. Kramer K. Nakatsuru and C. Spry. (1988), The tempo of reproduction in Hyphessobrycon pulchripinnis (Characidae), with a discussion on the biology of "multiple spawning" in fishes. Environmental Biology of fishes, 22(1): 1527.

Garutti, V. (1990), Caráter sexual secundário em Astyanax bimaculatus (Ostariophysi, Characidae) relacionado às nadadeiras anal e pélvicas. Naturalia, 15: 109-119.

Gelain, D., C. B. Fialho and L. R. Malabarba. (1999), Biologia reprodutiva de Serrapinus calliurus (Characidae, Cheirodontinae) do arroio Ribeiro, Barra do Ribeiro, Rio Grande do Sul, Brasil. Comunicações do Museu de Ciência e Tecnologia, PUCRS, Sér. Zool., 12: 71-82.

Godoy, M. P. de. (1975), Peixes do Brasil: subordem Characoidei, bacia do rio Mogi Guaçu. Editora Franciscana, Piracicaba, São Paulo. 4: 629-847.

Gonçalves, T. K., M. A. Azevedo, L. R. Malabarba and C. B. Fialho (2005), Reproductive Biology and development of sexually dimorphic structures in Aphyocharax anisitsii (Ostariophysi: Characidae). Neotropical Ichthyology 3(3): 433-438.

Kramer, D. L. (1978), Reproductive seasonality in fishes of a tropical stream. Ecology, 59 (5): 976-985.

Lampert, V. R., M. A. Azevedo and C. B. Fialho. (2004), Reproductive biology of Bryconamericus iheringii (Ostariophysi: Characidae) from rio Vacacaí, RS, Brazil. Neotropical Ichthyology 2(4): 209-215.

Malabarba, L. R. and S. H. Weitzman. (2003), Description of a new genus with six new species from southern Brazil, Uruguay and Argentina, with a discussion of a putative Characid clade (Teleostei: Characiformes: Characidae). Comunicações do Museu de Ciência e Tecnologia, PUCRS, Sér. Zool., 16(1): 67-151.

Menezes, N. A. and A. E. de M. Vazzoler. (1992), Reproductive characteristics of Characiformes. In: W. C. Hamlett (ed.): Reproductive biology in the South American vertebrates. New York: Springer-Verlag, pp. 60-70. 
Nakatani, K., A. A. Agostinho, G. Baumgartner, A. Bialetzki, P. V. Sanches, M. C. Makrakis and C. S. Pavanelli. (2001), Ovos e larvas de peixes de água doce: desenvolvimento e manual de identificação. Maringá: EDUEM. xviii, 378p.:il.

Oliveira, C. L. C., C. B. Fialho and L. R. Malabarba. (2002), Período reprodutivo, desova e fecundidade de Cheirodon ibicuhiensis Eigenmann, 1915 (Ostariophysi: Characidae) do arroio Ribeiro, Rio Grande do Sul, Brasil. Comunicações do Museu de Ciência e Tecnologia, PUCRS, sér. Zool. 15(1): 3-14.

Oliveira, C. L. C. (2003), Análise comparada de caracteres reprodutivos e da glândula branquial de duas espécies de Cheirodontinae (Teleostei: Characidae). M. Sc. Dissertation, Universidade Federal do Rio Grande do Sul, Porto Alegre, Brasil. 80p.

Reis, R. E., S. O. Kullander, and C. J. Ferraris Jr. (eds.). (2003), Check list of freshwater fishes of South and Central America. EDIPUCRS, Porto Alegre, 742p.

Santos, E. P. dos. (1978), Dinâmica de populações aplicada à pesca e piscicultura. São Paulo: HUCITEC, Editora da Universidade de São Paulo, 1978. 129 p.

Silva, J. F. P. (1998), Revisão taxonômica das espécies de Bryconamericus (Eigenmann, 1907) do Sul e Sudeste do Brasil (Osthariophysi: Characidae). M. Sc. Dissertation, Pós-Graduação em Biociências Zoologia, Pontifícia Universidade Católica do Rio Grande do Sul, Porto Alegre, 107p.
Vari, R. P. and D. J. Siebert. (1990), A New unusually sexually dimorphic species of Bryconamericus (Pisces: Ostariophysi: Characidae) from the Peruvian Amazon. Washington. Proceedings of the Biological Society of Washington, 103(3): 516-524.

Vazzoler, A. E. A. de M. (1996), Biologia da reprodução de peixes teleósteos: teoria e prática. Maringá, Editora da Universidade de Maringá, 169p.

Vazzoler, A. E. A. de M. and N. A. Menezes. (1992), Síntese de conhecimentos sobre o comportamento reprodutivo dos Characiformes da América do Sul (Teleostei, Ostariophysi). Revista Brasileira de Biologia, 52(4):627-640.

von Ihering, R. and P. Azevedo. (1936), As piabas dos açudes nordestinos (Characidae: Tetragonopterinae). Archivos do Instituto Biológico de São Paulo. 7: 75$106+12$ est.

Wiley, M. L. and B. B. Collette. (1970), Breeding tubercles and contact organs in fishes, their occurrence, structure, and significance. Bulletin of the American Museum of Natural History, 143: 143210.

Winemiller, K. O. (1989), Patterns of variation in life history among South American fishes in seasonal environments. Oecologia, 81:225-241.

Wootton, R. (1990), Ecology of Teleost Fishes. Fish and fisheries series 1. New York, Chapman and Hall. 404 p. 